\title{
The role of communication in the political and administrative management of national projects in the Yaroslavl region
}

\author{
Yu. A. Golovin 1 , O. V. Petrova ${ }^{1}$ \\ 1P. G. Demidov Yaroslavl State University, 14 Sovetskaya str., Yaroslavl 150003, Russian Federation \\ DOI: $10.18255 / 2412-6519-2021-1-6-17$ \\ Research Article \\ Full text in Russian
}

The article deals with the main aspects of political and administrative management at the present stage. The main components, a common goal and management methods are synthesized. Elements that do not have institutional consolidation, as well as elements that form the organizational structure of management, are identified. The main tasks of state authorities in the context of constitutional innovations are considered. The main tools of the country's development as a legal democratic social state are considered. The forms of involvement of civil society and organizations in management are structured, which allow achieving a balance of public and individual interests. Aspects of the formation of requirements for indicators of national projects, as well as the modern system of management and implementation of national projects, including trends in the implementation of national projects in the region, are considered.

The role of communication in management in achieving the country's strategic development goals and managing national projects in the Yaroslavl region in particular is established. The analysis of communication links in the Yaroslavl region, noted the increasing cooperation and understanding within the nonprofit sector the nonprofit sector. An expert assessment of public control was obtained. The directions and causes of civil activity are analyzed. The main expectations of the "third sector" from the system of authorities are formulated, the role of the interactive Internet in the procedures of public participation in decision-making by authorities is established. Specific proposals are formulated to ensure the transparency of processes that establish feedback between citizens and the state, and the most effective elements in the political and administrative management of national projects in the region are considered.

Keywords: political and administrative management; state; civil society; national projects; communication; authorities; information

INFORMATION ABOUT THE AUTHORS

$$
\begin{array}{r|l}
\begin{array}{r}
\text { Golovin, Yury A. } \\
\text { (correspondence author) }
\end{array} & \begin{array}{l}
\text { E-mail: yagolovin@rambler.ru } \\
\text { Doc. Sc. (Politics), Professor }
\end{array} \\
\text { Petrova, Oksana V. } & \begin{array}{l}
\text { E-mail: Oksana79127@mail.ru } \\
\text { Deputy Director }
\end{array}
\end{array}
$$

Funding: RFBR, project 19-011-00268

For citation: Golovin Yu. A., Petrova O. V. The role of communication in the political and administrative management of national projects in the Yaroslavl region // Social'nye i gumanitarnye znanija. 2021. Vol. 7, No 1. P. 6-17. (in Russ.)

(C) Golovin Yu. A., Petrova O. V., 2021

This is an open access article under the CC BY license (https://creativecommons.org/licenses/by/4.0/) 


\section{Роль коммуникации в политико-административном управлении национальными проектами в Ярославской области}

\section{Ю. А. Головин ${ }^{1}$, О. В.Петрова ${ }^{1}$}

1Ярославский государственный университет им. П. Г. Демидова, ул. Советская, 14, Ярославль, 150003, Российская Федерация

DOI: 10.18255/2412-6519-2021-1-6-17

УдК 321.01
Научная статья Полный текст на русском языке

В статье рассматриваются основные аспекты политико-административного управления на современном этапе. Синтезированы основные составляющие, единая цель и методы управления. Выявлены элементы, не имеющие институционального закрепления, а также элементы, формирующие организационную структуру управления. Рассмотрены основные задачи органов государственной власти в контексте конституционных новаций. Рассмотрены основные инструменты развития страны как правового демократического социального государства. Структурированы формы вовлечения гражданского общества и организаций в управление, позволяющие достигать баланса общественных и индивидуальных интересов. Рассмотрены аспекты формирования требований к показателям национальных проектов, а также современная система управления национальными проектами и их реализации, в том числе тенденции реализации национальных проектов в регионе. Установлена роль коммуникации в управлении при достижении стратегических целей развития страны в целом и управлении национальными проектами в Ярославской области в частности. Проведен анализ коммуникативных связей в Ярославской области, отмечено наращивание всестороннего взаимодействия и взаимопонимания внутри некоммерческого сектора. Получена экспертная оценка проведения общественного контроля. Проанализированы направления и причины гражданской активности. Сформулированы основные ожидания «третьего сектора» от системы органов власти, установлена роль интерактивной сети Интернет в процедурах участия общественности в принятии решений органами власти. Сформулированы конкретные предложения, обеспечивающие прозрачность процессов, устанавливающих обратную связь между гражданами и государством, рассмотрены наиболее эффективные элементы в политико-административном управлении национальными проектами в регионе.

Ключевые слова: политико-административное управление; государство; гражданское общество; национальные проекты; коммуникация; органы власти; информация

ИНФОРМАЦИЯ ОБ АВТОРАХ

\begin{tabular}{r|l} 
Головин, Юрий Алексеевич & E-mail: yagolovin@rambler.ru \\
(автор для корреспонденции) & Доктор политических наук, профессор \\
Петрова, Оксана Валерьевна & $\begin{array}{l}\text { E-mail: Oksana79127@mail.ru } \\
\text { Заместитель директора департамента дорожного хозяйства } \\
\text { Ярославской области }\end{array}$
\end{tabular}

Финансирование: РФФИ, проект № 19-011-00268 «Трансформация гражданской активности в условиях развития информационно-коммуникативных технологий (на примере Ярославской области)»

Для цитирования: Головин Ю. А., Петрова О. В. Роль коммуникации в политико-административном управлении национальными проектами в Ярославской области // Социальные и гуманитарные знания. 2021. Том 7, № 1. С. 6-17.

(С) Головин Ю. А., Петрова О. В., 2021

Статья открытого доступа под лицензией СС BY (https://creativecommons.org/licenses/by/4.0/) 
Вопросы поиска новых путей совершенствования государственного регулирования, а также предложение эффективных способов решения сложных проблем политико-административного управления волнуют человечество на протяжении всего развития цивилизации.

Современное политико-административное управление представляет собой систему сформированных исторических традиций и ценностей, организованного взаимодействия органов власти и институтов гражданского общества по вопросам реализации важнейших политических и административных решений [1, с. 12].

Попробуем сформировать несколько основных элементов политико-административного управления [2, с. 787]. Во-первых, образцы поведения и нравы самоорганизации людей, поддержанные и ставшие традицией в сфере управления. Во-вторых, процедуры взаимодействия самих органов власти, а также процедуры взаимодействия с институтами гражданского общества и с неорганизованными гражданами. B-третьих, сами институты, регулирующие функционирование отношений власти и управления. Все составляющие имеют единую цель и реализуются в процессе подготовки, принятия и организации исполнения решений, а также осуществления контроля их исполнения [3, с. 41].

На практике мы видим, что не все составляющие системы политико-административного управления регулируются нормативно, лишь некоторые из них имеют институциональное закрепление и реализуются через специально созданные учреждения. При этом важные элементы, формирующие организационную структуру управления, такие как цели, задачи, полномочия, ответственность, могут отражаться только в правовом регулировании системы органов власти как основного источника формирования и влияния на административное управление.

На наш взгляд, главной задачей государственных органов власти является развитие государства и общества через научно-техническое развитие и политический процесс. Современное управление реализуется программными методами с постоянным применением инноваций. Комплексный подход в России получил развитие с начала 2000-х годов в виде федеральных целевых программ (ФЦП). 5 сентября 2005 года на расширенном совещании с членами Правительства Российской Федерации, руководством Федерального Собрания Российской Федерации и членами Президиума Госсовета Российской Федерации Президент Российской Федерации объявил о начале реализации приоритетных национальных проектов (далее - нацпроектов). Основное отличие нацпроектов от всех программных мероприятий заключалось в единой концентрации финансовых ресурсов по приоритетным направлениям социально-экономического развития страны. С 1 января 2006 года в России началась реализация четырех нацпроектов: «Здоровье», «Доступное и комфортное жилье - гражданам России», «Образование» и «Развитие агропромышленного комплекса (АПК)». В 2016-2018 годах были утверждены паспорта уже 29 приоритетных проектов (например, «Современная цифровая образовательная среда в Российской Федерации», «Формирование здорового образа жизни» и многие другие).

Динамика жизни России отражалась и на политико-административном управлении. Государственным институтам уже недостаточно было ориентироваться на простое достижение целей, требовалась перенастройка для наивысшей эффективности работы системы власти через синхронизацию процессов управления с потребностями народа.

Новыми положениями Конституции Российской Федерации, одобренной первого июля 2020 года, определен вектор развития, направленный на повышение дове- 
рия в стране как правового демократического социального государства. Согласно одной из конституционных новаций, в России во всех сферах жизни должны быть созданы основы для взаимного доверия государства и общества.

Вовлечение гражданского общества и организаций в управление через возможность влиять на формирование, реализацию решений, осуществление контроля их исполнения позволяет обеспечивать баланс общественных и индивидуальных интересов. Поэтому становление гражданского общества в России также важно при формировании демократической системы политико-административного управления. Создание механизмов прямого участия граждан в формировании комфортных условий для повышения качества и комфортности среды проживания становится национальной целью развития России 1 .

Основным инструментом достижения стратегических целей современного развития страны являются национальные проекты [4]. Успех реализации национальных проектов и программ в значительной степени зависит от эффективной работы регионов $^{2}$. Именно региональным управленческим командам предстоит играть главную роль в решении конкретных практических задач. В регионах, в том числе в Ярославской области, сформирована современная система управления и реализации национальных проектов, представленная проектными офисами (комитеты) ${ }^{3}$. Она обеспечивает координацию усилий всех органов власти и местного самоуправления, экспертных и общественных организаций ${ }^{4}$. Софинансирование расходов субъектов Федерации на реализацию национальных проектов осуществляется путем предоставления трансфертов из федерального бюджета. До 2024 года на реализацию национальных проектов предусмотрено более двадцати триллионов рублей федеральных средств [5]. Уровень социально-экономического развития регионов различается и очень значительно. Субъекты имеют разные стартовые условия и разные возможности в процессе реализации национальных проектов, поэтому при формировании показателей используется принцип индивидуального подхода к регионам, детально учитывающий их возможности.

Участие Ярославской области в реализации национальных проектов представлено практически всеми основными социально-значимыми направлениями и осуществляется через формат региональных проектов, которых в настоящее время насчитывается несколько десятков, они включены в состав практически всех региональных программ [6]. В настоящее время на территории области реализуются нацпроекты «Здравоохранение», «Образование», «Жилье и городская среда», «Культура», «Производительность труда и поддержка занятости», «Цифровая экономика», «Экология», «Демография», «Малое и среднее предпринимательство и поддержка индивидуальной предпринимательской инициативы», «Безопасные и качественные ав-

\footnotetext{
1 Указ Президента Российской Федерации от 21.07.2020 № 474 «О национальных целях развития России до 2030 года». Консультант Плюс. URL: https://www.consultant.ru (дата обращения: 06.01.2021).

2 Постановление Правительства Российской Федерации от 31.10.2018 № 1288 «Об организации проектной деятельности в Правительстве Российской Федерации». Консультант Плюс. URL: https://www.consultant.ru (дата обращения: 06.01.2021).

${ }^{3}$ Постановление Правительства Ярославской области от 13.12.2017 № 929-п «Об утверждении состава регионального проектного комитета» (с изменениями на 16.04.2020). Консультант Плюс. URL: https://www.consultant.ru (дата обращения: 06.01.2021).

${ }^{4}$ Постановление Правительства Ярославской области от 28.09.2018 № 717-п «Об утверждении Плана мероприятий («дорожной карты») по реализации в Ярославской области Указа Президента в Российской Федерации от 07 мая 2018 года № 204». Консультант Плюс. URL: https://www.consultant.ru (дата обращения: 06.01.2021).
} 
томобильные дороги». Только в 2020 году общее финансирование всех национальных проектов в регионе составило более двенадцати миллиардов рублей, в том числе из федерального бюджета было выделено более девяти миллиардов. Тройка самых капиталоемких национальных проектов в регионе обусловлена спецификой региональных потребностей. Лидирующие позиции занимает проект, направленный на приведение к нормативному состоянию сети автомобильных дорог в регионе. Финансирование этого национального проекта по сравнению с 2018 годом увеличилось в три раза и составило в 2020 году более 4 миллиардов рублей. Действительно, объемы дорожного строительства впечатляют и значительно превышают совокупный предыдущий десятилетний период. Только в 2020 году было отремонтировано более 170 километров дорог. Далее по инвестициям следует проект «Демография», тройку лидеров замыкает проект «Жилье и городская среда». Плановые значения финансирования этих проектов в 2021 году приблизятся к десяти миллиардам рублей.

В первую очередь такие инвестиции направлены на повышение качества жизни жителей региона. Понимание правильности принятия управленческих решений обеспечивается коммуникацией с гражданским обществом. Далеко не везде и не всегда люди чувствуют результаты реализации национальных проектов, даже там, где эти результаты по факту есть. Существуют примеры, когда принятые решения приходилось пересматривать только потому, что их суть, смысл и пользу гражданам вообще не объясняли [7]. Информационное сопровождение нацпроектов и вовлечение населения и институтов гражданского общества в процесс их реализации должны стать одной из важнейших составляющих. Поэтому при принятии решений в регионе широко используются совещательные формы, в том числе с помощью онлайн-голосования или презентации проектных решений. На этапе реализации участие представителей основных общественных организаций поддерживается выездами на объекты. Контроль исполнения проектов обеспечивается участием в сдаче объектов. Используются формы обратной связи через социальные сети, мобильные приложения, ответы органов власти на официальные обращения граждан.

В феврале-марте 2020 года среди представителей общественных и некоммерческих организаций, осуществляющих деятельность на территории Ярославской области, был проведен экспертный опрос, целью которого было описать характер взаимоотношений общественных объединений и некоммерческих организаций с элементами гражданского общества (таблицы 1,2 ). Всего в опросе приняли участие 72 эксперта (руководители и сотрудники общественных и некоммерческих организаций Ярославской области).

таблица 1

Распределение участников опроса по опыту работы в некоммерческой организации

\begin{tabular}{|l|l|l|}
\hline Опыт работы & Частота & Процент \\
\hline до 1 года & 2 & $2,8 \%$ \\
\hline от 1 до 3 лет & 8 & $11,1 \%$ \\
\hline от 3 до 5 лет & 5 & $6,9 \%$ \\
\hline от 5 до 7 лет & 4 & $5,6 \%$ \\
\hline от 7 до 10 лет & 9 & $12,5 \%$ \\
\hline свыше 10 лет & 35 & $48,8 \%$ \\
\hline Не указали & 9 & $12,5 \%$ \\
\hline
\end{tabular}




\section{Распределение участников опроса по географии}

\begin{tabular}{|l|l|l|}
\hline География экспертного опроса & Частота & Процент \\
\hline г. Ярославль & 25 & $34,7 \%$ \\
\hline г. Рыбинск & 3 & $4,2 \%$ \\
\hline Даниловский МР & 9 & $12,5 \%$ \\
\hline Угличский МР & 5 & $6,9 \%$ \\
\hline Любимский МР & 1 & $1,4 \%$ \\
\hline Большесельский МР & 3 & $4,2 \%$ \\
\hline Пошехонский МР & 4 & $5,6 \%$ \\
\hline Борисоглебский МР & 2 & $2,8 \%$ \\
\hline Первомайский МР & 1 & $1,4 \%$ \\
\hline Тутаевский МР & 1 & $1,4 \%$ \\
\hline г.о. Переславль-Залесский & 4 & $5,6 \%$ \\
\hline Ярославский МР & 1 & $1,4 \%$ \\
\hline Ростовский МР & 1 & $1,4 \%$ \\
\hline Мышкинский МР & 2 & $2,8 \%$ \\
\hline Гаврилов-Ямский МР & 3 & $4,2 \%$ \\
\hline Не указали & 7 & $9,7 \%$ \\
\hline
\end{tabular}

В исследование были включены сотрудники некоммерческих организаций с различным опытом работы (от одного года до 10 и более лет), осуществляющие свою деятельность в различных населенных пунктах региона.

В Ярославской области, начиная с 2013 года, идет наращивание всестороннего взаимодействия и взаимопонимания внутри некоммерческого сектора (диаграмма 1). Темпы впечатляющие, рост участников сотрудничества составил 12,6 п.П., единодушия - 24,7 п.п. Речь уже идет о понимании общественников необходимости тесной кооперации, использования потенциала друг друга для достижения общих целей.

Рост взаимопонимания улучшает общий фон взаимодействия с государственными структурами. В 2019 году имели общие дела и проекты с ними 85,3 \% представителей «третьего сектора» региона, общение проходило с полным взаимопониманием у 41,5 \% (в 2018 году - 86,4 \% и 35,8 \% соответственно). Чаще всего контакты осуществлялись с департаментом общественных связей Ярославской области (16,7 \%), местными органами власти $(11,1 \%)$, департаментом образования $(8,3 \%)$, департаментом туризма (6,9 \%), мэрией города Ярославля $(6,9 \%)$, администрацией Большесельского муниципального района (5,6 \%), администрацией Угличского муниципального района (4,2%), Администрацией города Переславля-Залесского (4,2%).

Рост активности некоммерческих и общественных организаций в плане поиска союзников и партнеров среди органов власти в 2019 году продиктован не практической (рабочей) необходимостью, а улучшением отношений с ними и ростом взаимопонимания между ними. И если 2018 год был продуктивнее предыдущих пяти лет, то 2019 год оказался несколько плодотворнее.

Экспертные оценки развития общественного контроля в регионе по итогам 2019 года практически не изменились и зафиксированы на уровне 4,72 балла (- 0,16 п.). Стабильность оценок наблюдается в течение трёх последних лет. В большинстве случаев подобная картина рассматривалась бы как положительный момент, но не в данном случае. 

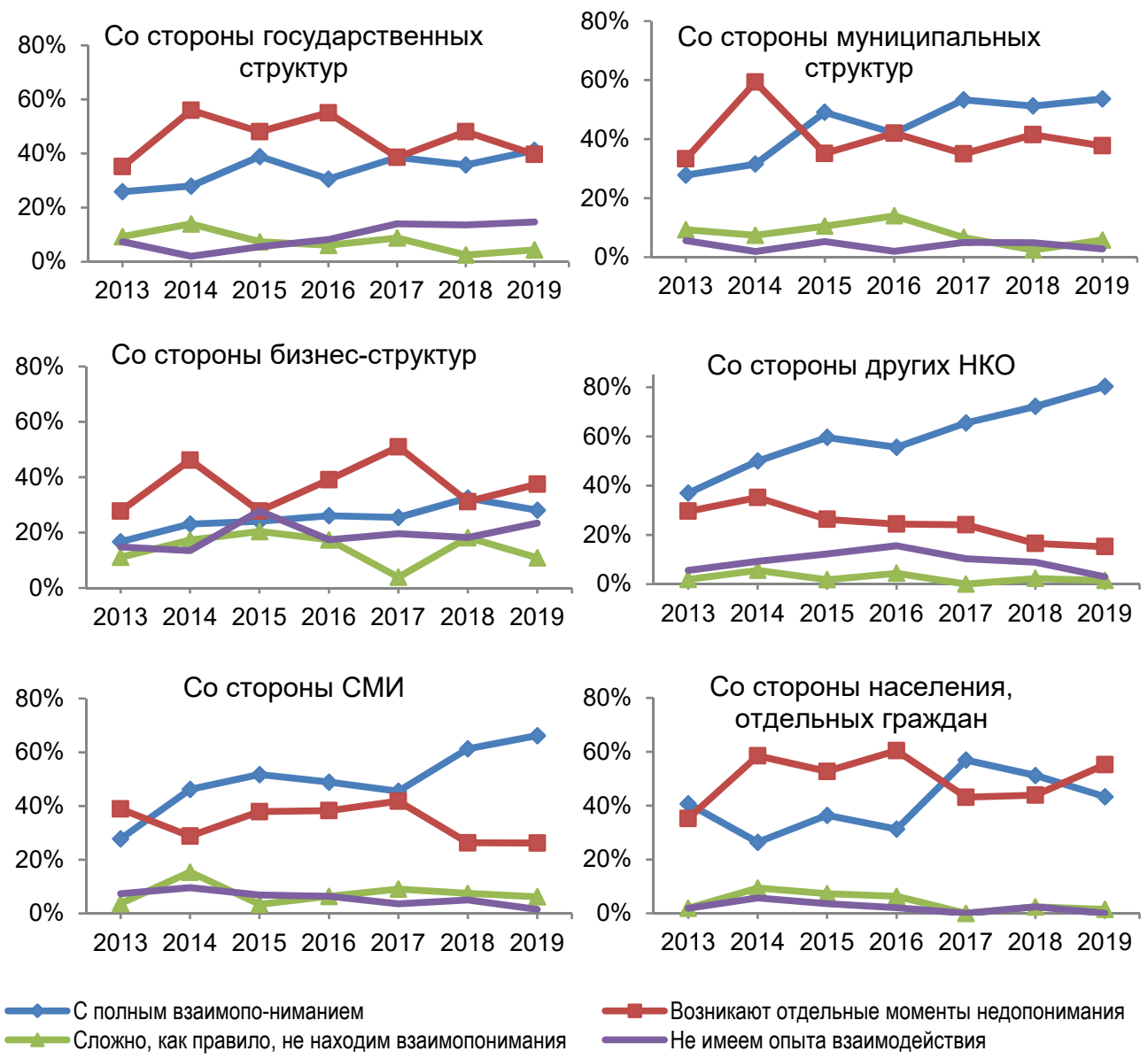

$\longrightarrow$ С полным взаимопо-ниманием

$\longrightarrow$ Сложно, как правило, не находим взаимопонимания

- Возникают отдельные моменты недопонимания
Не имеем опыта взаимодействия

Диаграмма 1. Уровень взаимопонимания по отношению к НКО.

В региональном некоммерческом сообществе нет единого или более-менее консолидированного мнения о развитии «низовой» гражданской активности в Ярославской области. Относительное большинство говорит, что она уступает институциональной $(40,9 \%)$. В то же время велика доля тех, кто разделяет мнение о равном уровне их развития $(34,8 \%)$. Еще $12,1 \%$ полагают, что неинституционализированная сегодня развита лучше активности НКО. Столько же затруднились ответить на соответствующий вопрос.

Мнение о развитии «низовой» гражданской активности, как показывают результаты исследования (диаграмма 2), зависит от стажа работы общественника в некоммерческом секторе и от его места жительства. Так, ответ «развита лучше (институциональной)» чаще всего выбирали те, чья организация работает от 5 до 10 лет, а также осуществляющие свою деятельность в г. Ярославле, г. Рыбинске и Большесельском муниципальном районе. 


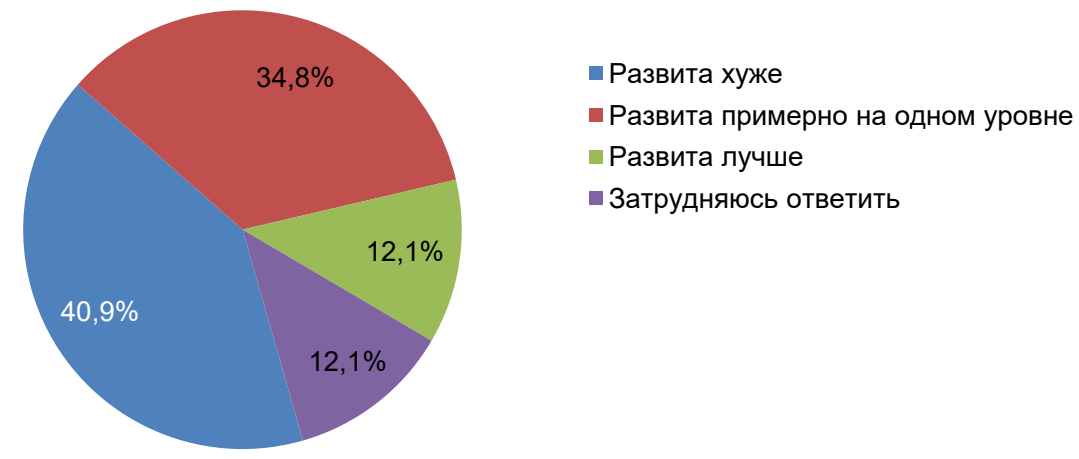

Диаграмма 2. Распределение ответов на вопрос: «Как Вы считаете, насколько развита в Ярославской области неинституционализированная, «низовая» гражданская активность (активность отдельных граждан, не участвующих в деятельности НКО) в сравнении с активностью НКО?»

По мнению экспертов, наиболее часто гражданская активность в Ярославской области представлена добровольчеством и волонтерством, а также действиями в Интернете (в т. ч. письма и обращения в органы власти) (диаграмма 3), несколько реже - участием в деятельности общественных организаций, ТСЖ.

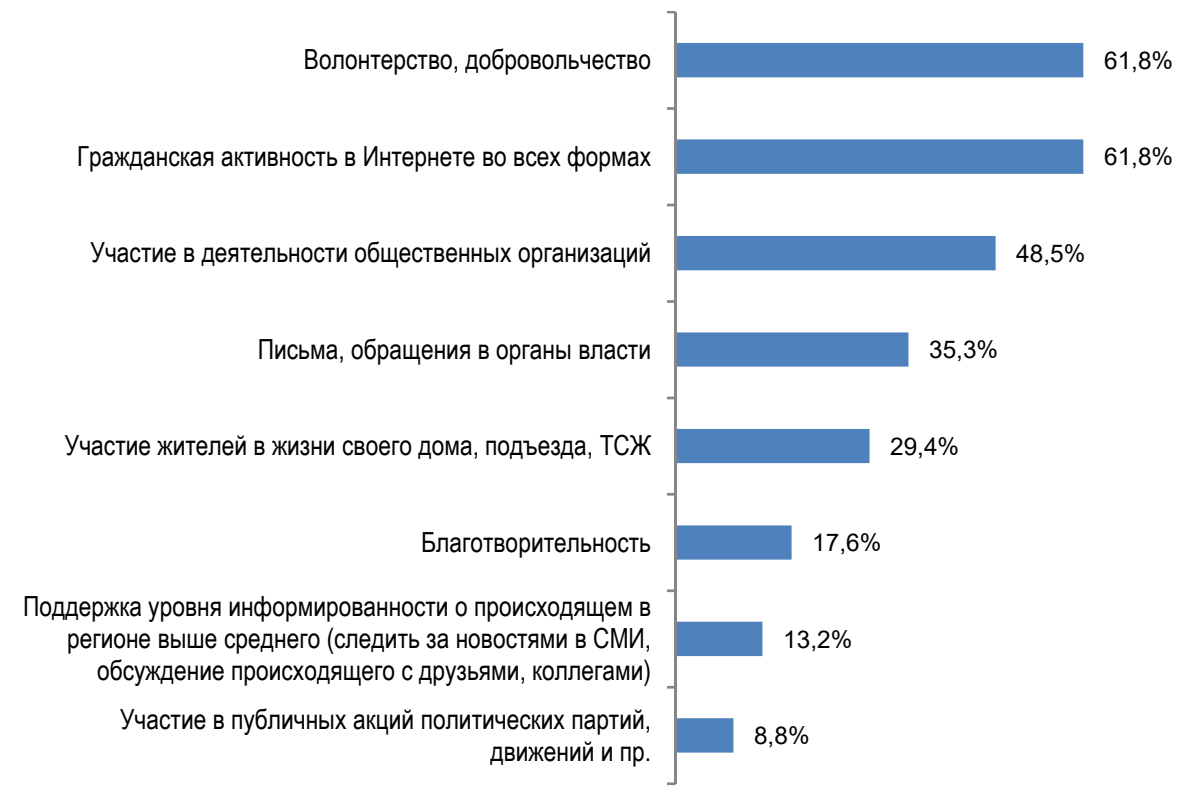

Диаграмма 3. Распределение ответов экспертов на вопрос: «Какими формами, на Ваш взгляд, преимущественно представлена гражданская активность

в Ярославской области? (до 3-х вариантов ответа)» 
По мнению экспертов, государственный заказ для НКО в Ярославской области сместился в сторону патриотического воспитания, привития населению государственно важных ценностей и решения социальных проблем (без привлечения государства), хотя и остается гетерогенным. Это мнение характерно как для «молодых», так и для опытных общественников.

Эксперты уверены, что сегодня государство от них ждет (диаграмма 4) прежде всего решения социальных проблем (54,4 \%), снижения социальной напряженности $(47,1 \%)$, организации и /или участия в мероприятиях по повышению патриотических настроений и культивирования общепринятых ценностей в региональном социуме $(42,6 \%)$.

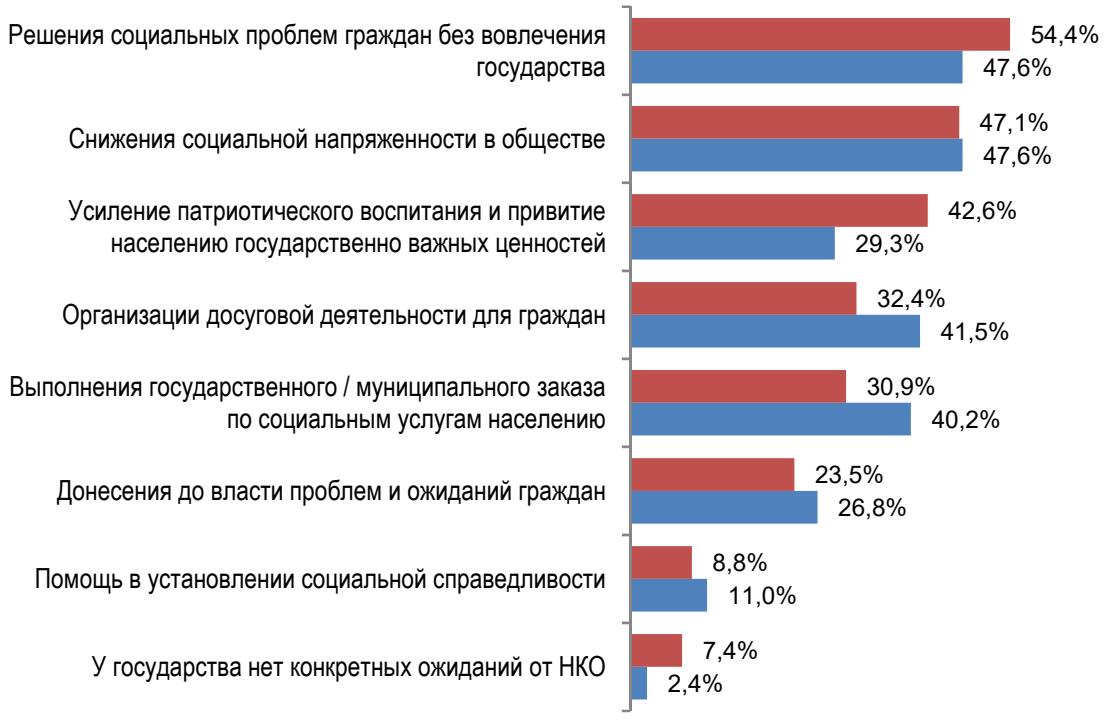

ш По данным на начало 2020 года По данным на начало 2019 года

Диаграмма 4. Распределение ответов экспертов на вопрос: «Как Вы считаете, что именно ждет государство от НКО? (можно выбрать несколько вариантов ответов)»

Выполнение государственного / муниципального заказа по социальным услугам населению уходит сегодня на второй план интересов органов власти, по мнению руководителей региональных некоммерческих организаций и общественных объединений. Своё мнение они строят, опираясь на общение с представителями власти и тематику грантов.

От государства общественники ожидали в 2020 году (диаграмма 5) прежде всего дальнейшего развития механизмов и форм финансовой и имущественной поддержки $(49,3$ \%) и стабильности $(35,8 \%)$.

Вопрос финансирования особенно важен для «молодых» организаций (стаж работы менее 5 лет), стабильность - для опытных (стаж работы более 5 лет).

Все эксперты используют Интернет (диаграмма 6). Как и год назад, их активность в сети чаще всего ограничивается рабочей необходимостью и социальным общением: поиск справочной информации $(85,3$ \%) и материалов для работы $(75,0 \%)$, работа по электронной почте $(94,1 \%)$, просмотр новостей $(57,4 \%)$ и общение в социальных сетях $(63,2 \%)$. 
Ожидаю стабильности, отсутствия изменений «правил

игры»

Создание условий для развития социального предпринимательства

Помощь в установлении социальной справедливости

Внедрение и развитие механизмов выполнения государственного / муниципального заказа по социальным услугам населению Затрудняюсь ответить Другое
Ожидаю минимизации присутствия государства в 3м
секторе

Диаграмма 5. Распределение ответов экспертов на вопрос: «Чего Вы ожидаете от государства в 2020 году?»

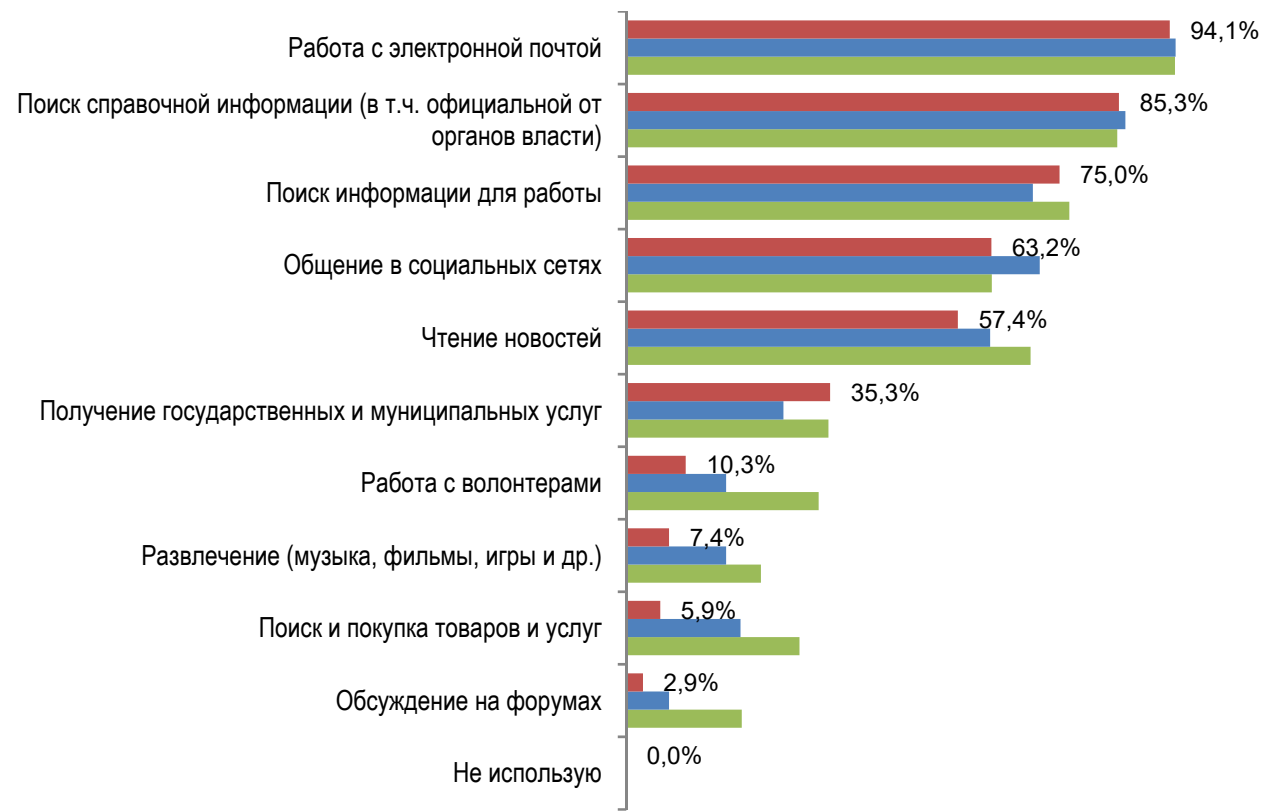

- По состоянию на февраль 2020 года — По состоянию на февраль 2019 года

- По состоянию на февраль 2018 года

Диаграмма 6. Распределение ответов респондентов на вопрос: «Скажите, пожалуйста, для каких целей Вы чаще всего используете Интернет?

(можно несколько ответов, но не больше 5)» 
За год мнение представителей некоммерческого сектора о ключевой роли Интернета в коммуникации с другими субъектами гражданского общества, органами власти и гражданами не изменилось. Как и раньше, подавляющее большинство из них считает, что наличие глобальной сети её упрощает $(87,9 \%$ ) (диаграмма 7 ).

$88,7 \% 88,9 \% 87,9 \%$

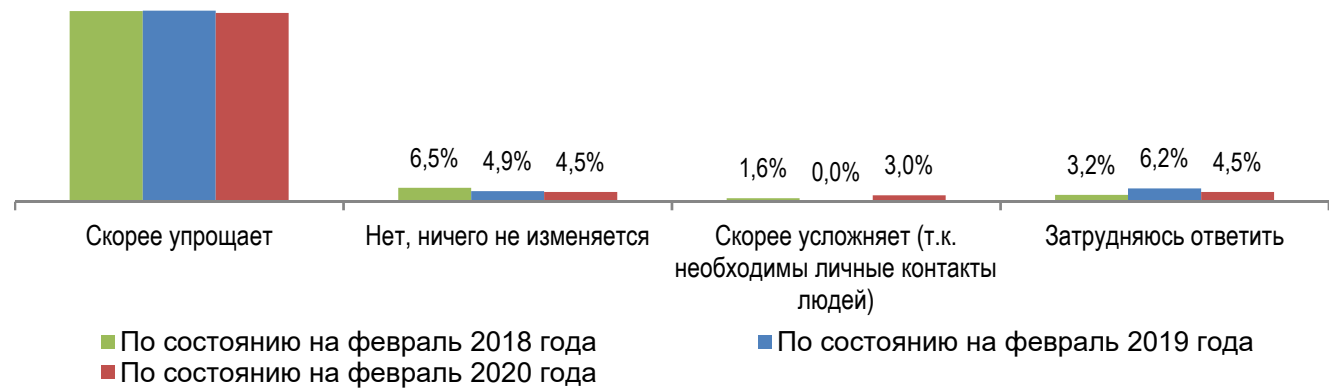

Диаграмма 7. Распределение ответов респондентов на вопрос: «Как Вы считаете, с точки зрения интересов НКО и гражданских активистов, развитие сети Интернет упрощает или нет коммуникацию с другими субъектами гражданского общества, органами власти и гражданами?»

Роль Интернета в процедуре участия общественников в принятии решений органами власти не столь однозначна. И в 2019 году этот вывод только укрепился. По данным на начало 2020 года, согласны с утверждением «взаимодействие с государством посредством сети Интернет повышает эффективность процедур контроля принятия решений органами власти» 58,5 \% экспертов (год назад их был 61 \%). Отдают решающую роль традиционным процедурам контроля принятия решений государством 7,7 \% (+4 п.п. к значению 2018 года).

Третий год подряд в некоммерческой сфере растет число убежденных в том, что «эффективность взаимодействия с государством не зависит от способа коммуникации». В 2018 году данную точку зрения разделяли 14,5 \%, в 2019 - 17,1 \%, в 2020 их стало уже 24,6 \% (диаграмма 8).

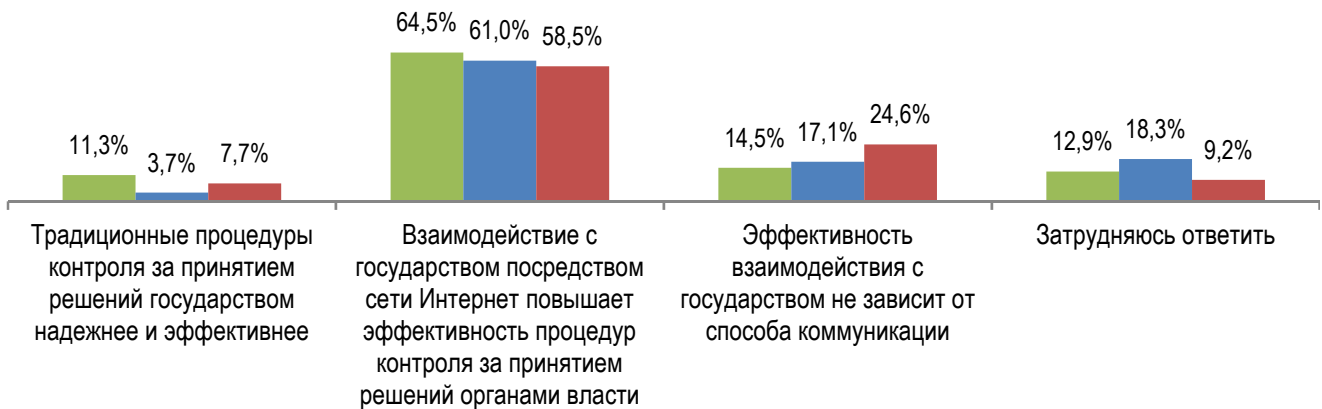

- По состоянию на февраль 2018 года

- По состоянию на февраль 2020 года

- По состоянию на фревраль 2019 года

Диаграмма 8. Распределение ответов респондентов на вопрос: «Как Вы считаете, с точки зрения интересов НКО и гражданских активистов, развитие сети Интернет упрощает или усложняет процедуры их участия в принятии решений органами власти?» 
Информационная и коммуникационная политика делает уверенные шаги к приобретению необходимых системных качеств государственной политики в сфере национальных проектов, что подтверждается результатами проведенного опроса. Необходимо и далее формировать механизмы, обеспечивающие прозрачность процессов, устанавливающих обратную связь между гражданами и государством, с использованием интерактивных инструментов вовлечения граждан - современных онлайн-сервисов и цифровых платформ. Однако в настоящее время в коммуникации использован не весь спектр возможных современных форм и методов информационных технологий, в том числе диалоговых форм работы с населением. На наш взгляд, достаточно эффективным элементом в политико-административном управлении национальными проектами, позволяющими усилить взаимодействие государства и общества, было бы формирование информационных разделов в региональных планах управления национальными проектами, введение критериев социальной оценки результативности реализации проектов, включение в составы властных управленческих структур представителей гражданского общества и экспертного сообщества, проведение экспертных советов с привлечением в качестве экспертов именно получателей результатов нацпроектов, а не исполнителей программ.

Таким образом, максимально формируя в России правовые демократические и социальные принципы, органы государственной власти вовлекают общественные организации и частных лиц в участие в национальных проектах.

\section{Ссылки / References}

1. Жирнов Н. Ф. Политико-административное управление: инновационные аспекты // Власть. 2007. № 7. С. 12.

2. Сморгунов Л. В. Политико-административное управление: теоретические подходы, модели и институты // Российская политическая наука: в 5 т. М.: РОССПЭН, 2008. Т. 5. C. 780-789.

3. Ефременко Д. В. Принятие политических решений в обществе риска: проблемы трансформации различных социальных рисков в политический риск // Политическое управление и публичная политика XXI века: Государство, общество и политические элиты. М., РОССПЭН, 2008. С. 35-46.

4. Материалы семинара-совещания руководителей аналитических служб аппаратов законодательных (представительных) и исполнительных органов государственной власти субъектов Российской Федерации (часть 1). 14 (728) Июнь 2019 // Совет Федерации Федерального Собрания Российской Федерации. Аналитические вестники. 05.06.2019. URL: http://council.gov.ru/activity/analytics/analytical_bulletins/105523/ (дата обращения: 07.01.2021).

5. Табах А. В. Национальные проекты: ожидания, результаты, перспективы // Эксперт РА. URL: https://raexpert.ru/researches/national_project_2020/ (дата обращения: 12.01.2021).

6. Троицкая Екатерина Николаевна // Портал органов государственной власти Ярославской области. URL:

https://www.yarregion.ru/Pages/government/person.aspx?PersonID=48 (дата обращения: 07.01.2021).

7. Совместное заседание Госсовета и Совета по стратегическому развитию и нацпроектам // Президент России. 23.12.2020. URL:

http://www.kremlin.ru/events/president/news/64736 (дата обращения: 08.01.2021). 